\title{
Magnetic Nanoparticles-Based Biomedical and Bioanalytical Applications
}

\section{Sandeep Kumar Vashist}

HSG-IMIT - Institut für Mikro- und Informationstechnik, Georges-Koehler-Allee 103, 79110 Freiburg, Germany

Magnetic nanoparticles (MNP) are typically 1-100 $\mathrm{nm}$ in diameter and consist of magnetic elements (such as iron, cobalt, nickel and their compounds). The past decade has witnessed tremendous applications of MNP in biomedicine and bioanalytical sciences [1-15] as they can be manipulated by magnetic field. The most prominent applications are the treatment of cancer [1], drug delivery [3-5], magnetic resonance imaging (MRI) [3,6,7], magnetic assays $[8,15]$ and theragnostics [9]. They have the unique ability to turn on and off their magnetic properties depending on temperature, which provides a great analytical tool for effective cancer therapy. Moreover, they display remarkable properties such as superparamagnetism, high field irreversibility and high saturation magnetization.

Ferrite nanoparticles (NP) are the most commonly used MNP, which become superparamagnetic when they are smaller than 128 $\mathrm{nm}$. The stability of ferrite NP in solution is increased by chemically modifying their surface by surfactants, silicones or phosphoric acid derivatives. Metallic NP has also been developed but they are difficult to handle and have unwanted side reactions. On the other hand, MNP with a magnetic core ( $\mathrm{Fe}$ or $\mathrm{Co}$ ) but with a nonreactive shell such as graphene have been recently developed and demonstrated to have higher chemical stability (in acidic and basic solution, and organic solvents), and higher magnetization. The most common techniques for MNP synthesis [10-12] include co-precipitation, thermal decomposition, microemulsion, aerosol/vapour methods, sol-gel reaction, polyol method, flow injection synthesis, flame spray pyrolysis, laser pyrolysis, pulsed laser ablation [13], electrochemical methods, sonolysis, magnetotactic bacteria, and other wet chemistries. Co-precipitation is the most extensively used and most convenient method for the synthesis of ferrite NPs of controlled sizes and magnetic properties. A wide range of surface chemistries have also been developed to enhance the biocompatibility of MNP [9-10]. Additionally, several procedures have been developed for the formation of magnetic composites [11].

The recently published editorial article by Martirosyan in 2012 [1] pertaining to the use of thermo sensitive magnetic nanoparticles for the treatment of cancer by hyperthermia, demonstrates the potential of MNP. The treatment of tumors by hyperthermia is undoubtedly the most promising biomedical application, where the tumor cells are destroyed due to their sensitivity to temperature in the range of 42 $45^{\circ} \mathrm{C}$. The increased perfusion and oxygenation of neoplastic hypoxic cells in tumor tissue by hyperthermia facilitates the absorption of chemotherapeutic drugs, thereby leading to more effective cancer therapy. Hyperthermia has anti-angiogenic and immunotherapeutic role due to the thermal shock proteins produced by stressed tumor cells. This is being employed clinically in certain parts of the world. Moreover, Food and Drug Administration (FDA) has also approved the use of microwave hyperthermia in conjunction with radiation for cancer treatment. The commercial MNP are non-selective and thus lead to overheating of surrounding normal tissue. Therefore, there is a stringent need for significantly improved hyperthermia agents and procedures, which are highly selective to tumor cells, lead to uniformly controlled induction heating, and prevent the necrosis of normal tissue.

The most commonly used MNP for hyperthermia have Curie temperature $\left(\mathrm{T}_{\mathrm{c}}\right.$ ) between $45-50^{\circ} \mathrm{C}$, which prevents overheating of neighbouring healthy cells as the MNP are unaffected by alternating magnetic fields above $50^{\circ} \mathrm{C}$. These include ultrafine alumina coated particles of substituted ferrite $\left(\mathrm{Co}_{1-\mathrm{x}} \mathrm{Zn}_{\mathrm{x}} \mathrm{Fe}_{2} \mathrm{O}_{4}\right)$, yttrium-iron garnet $\left(\mathrm{Y}_{3} \mathrm{Fe}_{5-\mathrm{x}} \mathrm{Al}_{\mathrm{x}} \mathrm{O}_{12}\right)$, copper nickel alloy $(\mathrm{CuNi})$, nickel chromium alloy $\left(\mathrm{Ni}_{1}\right.$ $\left.{ }_{\mathrm{x}} \mathrm{Cr}_{\mathrm{x}}\right), \mathrm{Gd}_{5}\left(\mathrm{Si}_{1-\mathrm{x}} \mathrm{Ge}_{\mathrm{x}}\right)_{4},\left(\mathrm{Gd}_{1-\mathrm{x}} \mathrm{R}_{\mathrm{x}}\right)_{5} \mathrm{Si}_{4}(\mathrm{R}=\mathrm{Ce}, \mathrm{Nd}, \mathrm{Er}$ and Ho$), \mathrm{La}-\mathrm{Ag}$ and La-Na perovskite manganites $\left(\mathrm{La}_{0.73} \mathrm{Sr}_{0.27} \mathrm{MnO}_{3}\right.$ and $\left.\mathrm{La}_{0.8} 2 \mathrm{Sr}_{0.18} \mathrm{MnO}_{3+\delta}\right)$, $\mathrm{Mg}_{1+\mathrm{x}} \mathrm{Fe}_{2-2 \mathrm{x}} \mathrm{Ti}_{\mathrm{x}} \mathrm{O}_{4}, \mathrm{Zn}$-doped Mn-ferrite $\left(\mathrm{Mn}_{1-\mathrm{x}} \mathrm{Zn}_{\mathrm{x}} \mathrm{O}\right)$, Gd-doped $\mathrm{Zn}$ ferrite $\left(\mathrm{ZnGd}_{\mathrm{x}} \mathrm{Fe}_{2-2 \mathrm{x}} \mathrm{O}_{4}\right)$, and $\mathrm{Ni}_{0.2} \mathrm{Ca}_{0.8} \mathrm{Gd}_{0.08} \mathrm{Fe}_{1.92}^{1-\mathrm{x}} \mathrm{O}_{4}$. Most of the MNP have been demonstrated to be biocompatible as they are made up of biological elements.

MNP can capture free floating cancer cells, which can then be carried out of the body. Moreover, they can be used for the detection of cancer by coating with antibodies specific to the targeted cancer cells or proteins. Additionally, they have been used for the detection of Gram negative and Gram positive bacteria by conjugating with carbohydrates. The MNP-based MRI technique is a truly amazing technique that can predict the development of Type-1 diabetes in subjects with a genetic predisposition to diabetes [7]. Multifunctional MNP (Figure 1) have also been used for the imaging of other diseases such as atherosclerosis and cancer [6]. MNP such as CoPt have been used as MRI contrast agent for transplanted neural stem cell detection. Moreover, they have been used as catalyst or catalyst supports in addition to the quick isolation of mRNA using the magnetic bead attached to a poly $\mathrm{T}$ tail. MNP have also been employed for the removal of heavy metals from waste water as they have very large surface-to-volume ratio and can lead to easy separation by applying a magnetic field.

The development of magnetic immunoassay [8] is another most prospective technology based on the use of magnetic beads either at the capture antibody stage or at the detection antibody stage. The capture antibody-bound magnetic beads can lead to rapid immunoassay as they can be instantaneously bound to the substrate using the magnet. But the use of detection antibody-bound magnetic beads in sandwich immunoassay can lead to their detection by a magnetometer, thereby obviating the use of costly colorimetric detectors.

The evaluation of the toxicity and biocompatibility of MNP is critical for in vivo applications. It has been demonstrated that the size, composition and surface chemistry of MNP play an important role in their intracellular uptake, biodistribution, macrophage distribution and cytotoxicity [9]. Presently, the lack of international guidelines to evaluate the toxicity of nanomaterials [16] is responsible for the lag in

*Corresponding author: Sandeep Kumar Vashist, HSG-IMIT - Institut für Mikround Informationstechnik, Georges-Koehler-Allee 103, 79110 Freiburg, Germany, E-mail: sandeep.kumar.vashist@hsg-imit.de

Received February 26, 2013; Accepted February 28, 2013; Published March 03, 2013

Citation: Sandeep Kumar V (2013) Magnetic Nanoparticles-Based Biomedical and Bioanalytical Applications. J Nanomed Nanotechol 4: e130. doi:10.4172/21577439.1000e130

Copyright: (c) 2013 Sandeep Kumar V. This is an open-access article distributed under the terms of the Creative Commons Attribution License, which permits unrestricted use, distribution, and reproduction in any medium, provided the original author and source are credited. 
Citation: Sandeep Kumar V (2013) Magnetic Nanoparticles-Based Biomedical and Bioanalytical Applications. J Nanomed Nanotechol 4: e130. doi:10.4172/2157-7439.1000e130

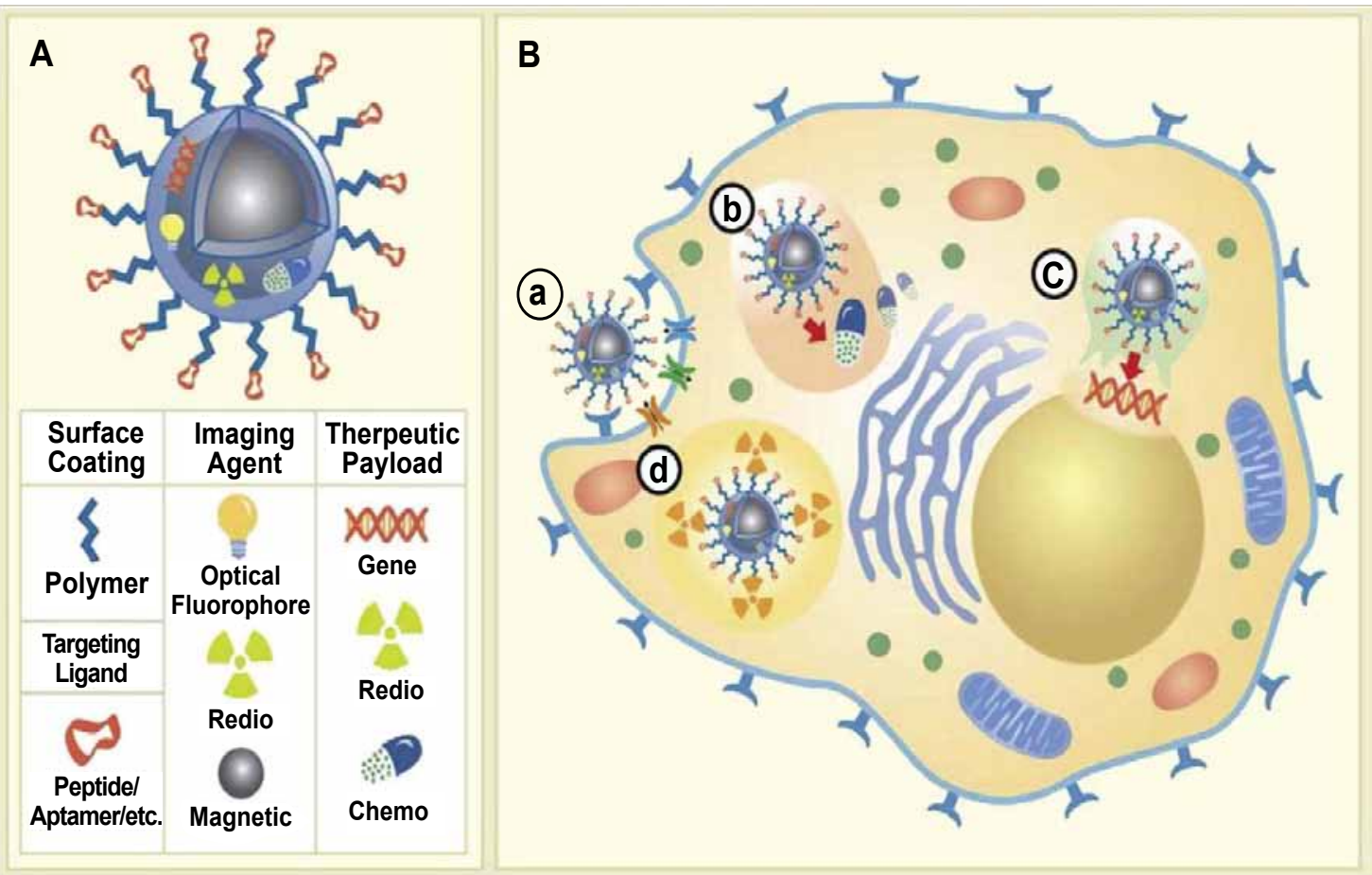

Figure 1: Multifunctional imaging/therapeutic magnetic nanoparticles (MNP) anatomy and potential mechanisms of action at the cellular level [4]. (A) A multifunctional MNP modified with targeting ligands extended from MNP surface with polymeric extenders, imaging reporters (optical, radio, magnetic), and potential therapeutic payloads (gene, radio, chemo). (B) Four possible modes of action for various therapeutic agents; a) Specific MNP binding to cell surface receptors (i.e. enzymes/ proteins) facilitate their internalization and/or inactivation, b) controlled intercellular release of chemotherapeutics; c) release of gene therapeutic materials post endosomal escape and subsequent targeting of nucleus; and d) intracellular decay of radioactive materials. Reproduced with permission from Elsevier B.V.

commercializing MNP-based products and processes. Additionally, the MNP-based products and processes must comply with the industrial and healthcare requirements [17]. However, based on their superior analytical performance, novel characteristic features and plethora of applications, MNPs will certainly play a key role in biomedicine and bioanalytical sciences in the near future.

\section{References}

1. Martirosyan KS (2012) Thermosensitive magnetic nanoparticles for selfcontrolled hyperthermia cancer treatment. J Nanomed Nanotechol 3: e112.

2. Mashhadizadeh MH, Amoli-Diva M (2012) Drug-carrying amino silane coated magnetic nanoparticles as potential vehicles for delivery of antibiotics. J Nanomed Nanotechol 3: 139

3. Sun C, Lee JS, Zhang M (2008) Magnetic nanoparticles in MR imaging and drug delivery. Adv Drug Deliv Rev 60: 1252-1265.

4. Veiseh O, Gunn JW, Zhang M (2010) Design and fabrication of magnetic nanoparticles for targeted drug delivery and imaging. Adv Drug Deliv Rev 62: 284-304.

5. Chomoucka J, Drbohlavova J, Huska D, Adam V, Kizek R, et al. (2010) Magnetic nanoparticles and targeted drug delivering. Pharmacol Res 62: 144149.

6. McCarthy JR, Weissleder R (2008) Multifunctional magnetic nanoparticles for targeted imaging and therapy. Adv Drug Deliv Rev 60: 1241-1251.

7. Fu W, Wojtkiewicz G, Weissleder R, Benoist C, Mathis D (2012) Early window of diabetes determinism in NOD mice, dependent on the complement receptor CRIg, identified by noninvasive imaging. Nat Immunol 13: 361-368.
8. Baniukevic J, Hakki Boyaci I, Goktug Bozkurt A, Tamer U, Ramanavicius A, et al. (2012) Magnetic gold nanoparticles in SERS-based sandwich immunoassay for antigen detection by well oriented antibodies. Biosens Bioelectron $43 \mathrm{C}$ 281-288.

9. Shubayev VI, Pisanic TR 2nd, Jin S (2009) Magnetic nanoparticles for theragnostics. Adv Drug Deliv Rev 61: 467-477.

10. Lu AH, Salabas EL, Schüth F (2007) Magnetic nanoparticles: synthesis protection, functionalization, and application. Angew Chem Int Ed Engl 46: 1222-1244.

11. Tartaj P, Morales MP, Gonzalez-Carreno T, Veintemillas-Verdaguer S, Serna CJ (2005) Advances in magnetic nanoparticles for biotechnology applications. J Magn Magn Mater 290-291: 28-34.

12. Laurent S, Forge D, Port M, Roch A, Robic C, et al. (2008) Magnetic iron oxide nanoparticles: synthesis, stabilization, vectorization, physicochemical characterizations, and biological applications. Chem Rev 108: 2064-2110.

13. Franzel L, Bertino MF, Huba ZJ, Carpenter EE (2012) Synthesis of magnetic nanoparticles by pulsed laser ablation. Appl Surf Sci 261: 332-336.

14. Tartaj P, Morales MP, Gonzalez-Carreno T, Veintemillas-Verdaguer S Gonzalez-Carreno T, et al. (2003) The preparation of magnetic nanoparticles for applications in biomedicine. J Phys D: Appl Phys 36: R182-R197.

15. Gijs MA, Lacharme F, Lehmann U (2010) Microfluidic applications of magnetic particles for biological analysis and catalysis. Chem Rev 110: 1518-1563.

16. Malloy TF (2011) Nanotechnology regulation: a study in claims making. ACS Nano 5: 5-12.

17. Vashist SK, Venkatesh AG, Mitsakakis K, Czilwik G, Roth G, et al. (2012) Nanotechnology-based biosensors and diagnostics: technology push versus industrial/healthcare requirements. BioNanoSci 2: 115-126. 